San Jose State University

SJSU ScholarWorks

Master's Theses

Master's Theses and Graduate Research

Summer 2017

\title{
The Moderating Effect of Leader-Member Exchange on the Relationship between Job Characteristics and Organizational Commitment
}

Caitlin Sullivan

San Jose State University

Follow this and additional works at: https://scholarworks.sjsu.edu/etd_theses

\section{Recommended Citation}

Sullivan, Caitlin, "The Moderating Effect of Leader-Member Exchange on the Relationship between Job Characteristics and Organizational Commitment" (2017). Master's Theses. 4862.

DOI: https://doi.org/10.31979/etd.2ku8-6d8p

https://scholarworks.sjsu.edu/etd_theses/4862

This Thesis is brought to you for free and open access by the Master's Theses and Graduate Research at SJSU ScholarWorks. It has been accepted for inclusion in Master's Theses by an authorized administrator of SJSU ScholarWorks. For more information, please contact scholarworks@sjsu.edu. 
THE MODERATING EFFECT OF LEADER-MEMBER EXCHANGE ON THE RELATIONSHIP BETWEEN JOB CHARACTERISTICS AND ORGANIZATIONAL COMMITMENT

\author{
A Thesis \\ Presented to \\ The Faculty of the Department of Psychology \\ San José State University \\ In Partial Fulfillment \\ of the Requirements for the Degree \\ Master of Science
}

by

Caitlin R. Sullivan

August 2017 
(C) 2017

Caitlin R. Sullivan

ALL RIGHTS RESERVED 
The Designated Thesis Committee Approves the Thesis Titled

THE MODERATING EFFECT OF LEADER-MEMBER EXCHANGE ON THE RELATIONSHIP BETWEEN JOB CHARACTERISTICS AND ORGANIZATIONAL COMMITMENT

by

Caitlin R. Sullivan

APPROVED FOR THE DEPARTMENT OF PSYCHOLOGY

SAN JOSÉ STATE UNIVERSITY

August 2017

Dr. Howard Tokunaga Department of Psychology

Dr. Altovise Rogers Department of Psychology

Dr. Megumi Hosoda Department of Psychology 


\begin{abstract}
THE MODERATING EFFECT OF LEADER-MEMBER EXCHANGE ON THE RELATIONSHIP BETWEEN JOB CHARACTERISTICS AND ORGANIZATIONAL COMMITMENT
\end{abstract}

by Caitlin R. Sullivan

There is a phrase "You don't leave the company; you leave a manager." But what if the job is perfectly designed to lead to organizational commitment: will the manager still have that much of an influence? This study examined the moderating effect of LeaderMember Exchange on the relationship between the Job Characteristics and Organizational Commitment. 220 employees from various countries and industries were surveyed regarding their current job, commitment to the organization and their relationship with their manager. Results showed that the core job dimensions based on the Job Characteristics Model were independently and uniquely related to affective and normative commitment, but not continuance commitment. Leader-Member Exchange did not moderate the relationship with any of the dimensions of commitment, but did add unique value to affective and normative commitment above and beyond the core job dimensions. Therefore, the relationship with one's manager effects the overall employee experience and can impact organizational commitment. However, relationship with one's manager did not moderate the relationship between the Job Characteristics and Organizational Commitment. This study provided more information regarding how managers' actions, communication, and trust can influence the commitment of employees, even if the structure of the job encourages commitment. Organizations can therefore have a better understanding of how to retain employees. 


\section{ACKNOWLEDGEMENTS}

I would like to thank my thesis committee for their amazing support, responsiveness, and dedication to my success. Howard, thank you for being my thesis chair and providing me with guidance, confidence, life talks, and impeccable patience throughout my time as a student at San Jose State University; especially during the intense path of completing my thesis. Altovise, thank you for your amazing attention to detail, quick turnaround, and intelligent conversations; both during the school year and in my time completing my thesis. I would also like to thank Megumi for stepping in when I needed her most to help me complete my thesis, as well as having humor, intelligence, and patience during my time in the program. Lastly, thank you Kimberley Lee for being my grammar guru and helping me keep my sanity during my last thesis push. Thank you, Katarina Schulz, for being the most amazing friend, editor, sanity keeper, and all around amazing person. I could not have done this without you - not an exaggeration.

To my friends, family, and colleague, thank you for your thoughtful words, food, and venting sessions when I thought the world would crumble. Your encouragement gave me the motivation and energy to keep moving forward and not give up. I am beyond grateful, I cannot put into words the amount of support I feel from those surrounding me and only hope to show my true appreciation. 


\section{TABLE OF CONTENTS}

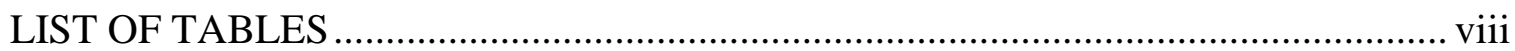

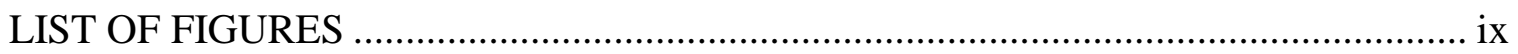

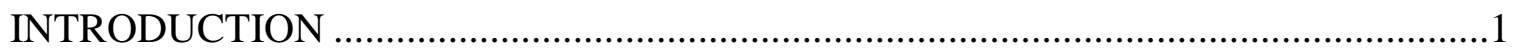

History of Organizational Commitment ….......................................................

The Value of Organizational Commitment.............................................................

Predictors of Organizational Commitment ..........................................................

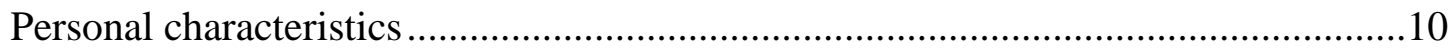

Organizational structural characteristics ....................................................... 10

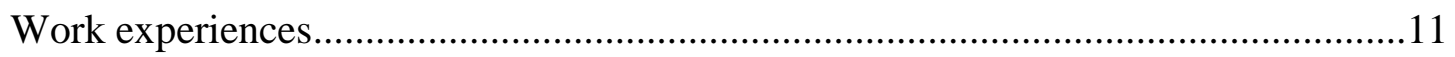

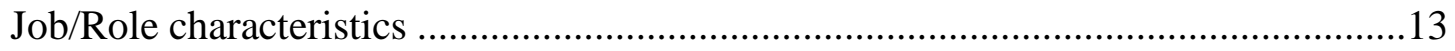

The Job Characteristics Model........................................................................... 14

Job Characteristics and Organizational Commitment............................................19

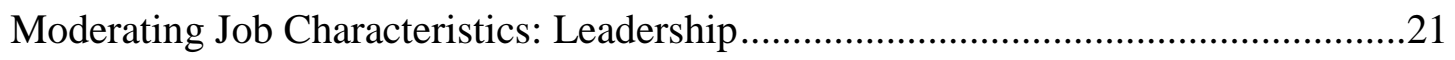

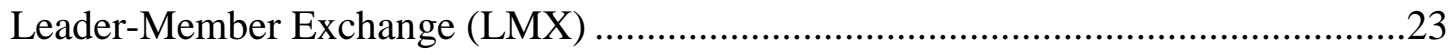

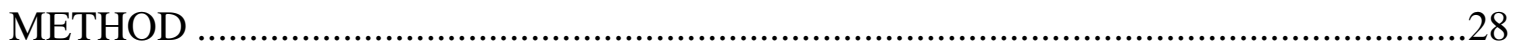

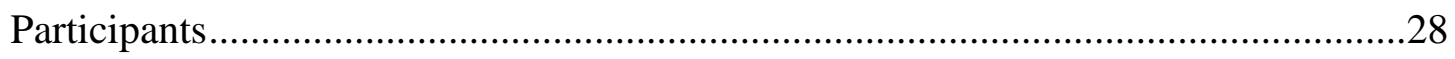

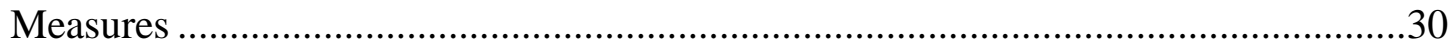




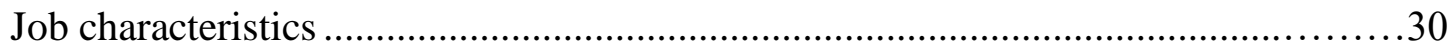

Leader-Member exchange ………………............................................................

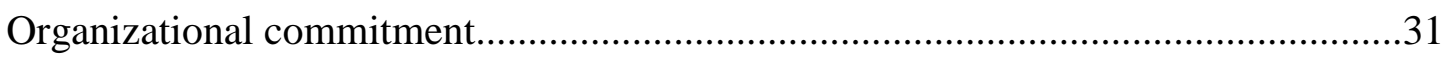

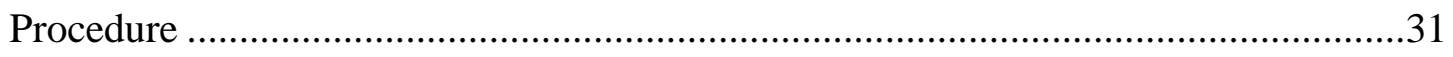

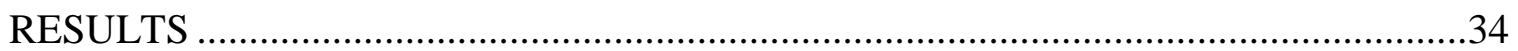

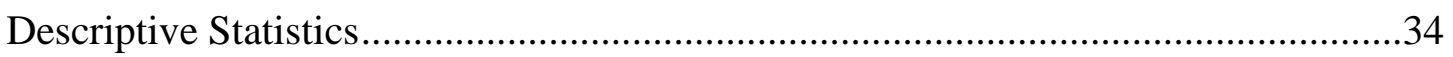

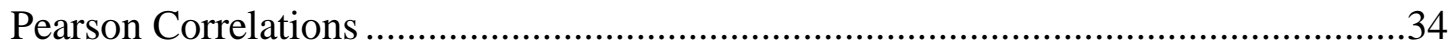

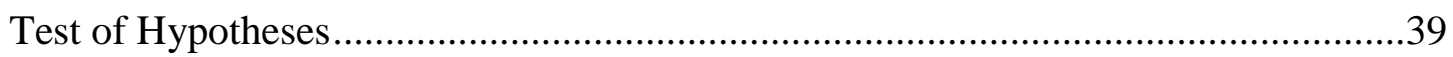

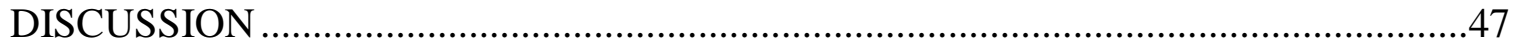

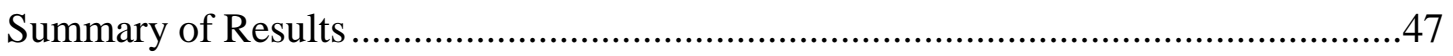

Theoretical Implications ……………………………....................................50

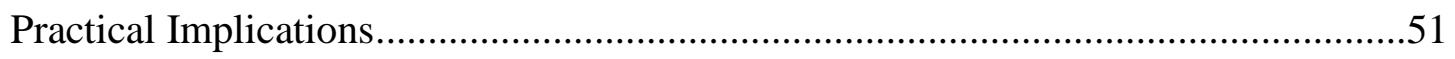

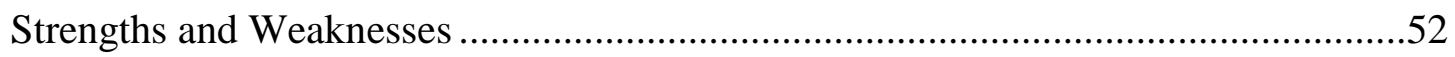

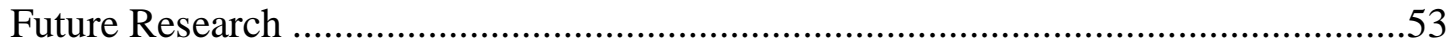

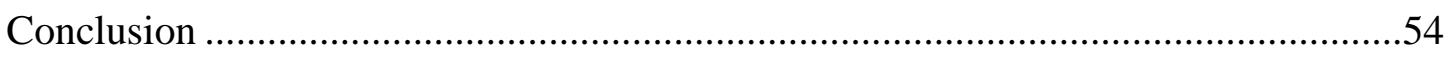

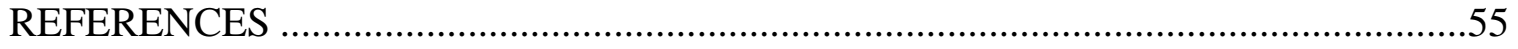

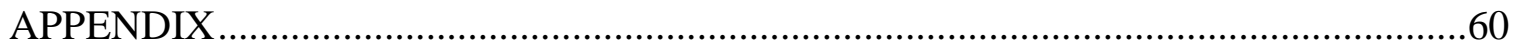




\section{LIST OF TABLES}

Table 1. Demographic Characteristics of Participants

Table 2. Means, Standard Deviations, and Cronbach Alphas of Core Job

Dimensions, LMX, and Commitment Dimensions

Table 3. Pearson Correlations for Core Job Dimensions, LMX, and

Commitment Dimensions

Table 4. Hierarchical Multiple Regression Analysis: Moderation of Leader-Member Exchange- Job Characteristics Relationship

By Affective Commitment

Table 5. Hierarchical Multiple Regression Analysis: Moderation of Leader-Member Exchange- Job Characteristics Relationship

By Normative Commitment..

Table 6. Hierarchical Multiple Regression Analysis: Moderation of Leader-Member Exchange- Job Characteristics Relationship

By Continuance Commitment. 


\section{LIST OF FIGURES}

Figure 1. Job Characteristics Model by Dimension ...............................................17

Figure 2. The Moderation Effect of LMX on Job Characteristics and Organizational Commitment ...................................................................26 


\section{Introduction}

There is a saying, "People don't leave their job or company, they leave their manager" (Lipman, 2015). But what if a job is perfectly designed to be motivating, engaging, and result in an employee being committed to the organization? Does a manager affect an employee's experience so much that the manager can convince a committed employee with an engaging job to leave, or a non-committed employee with a terrible job to remain at the organization? This paper aims to examine the influence a manager has on the relationship between job characteristics and organizational commitment.

The commitment referred to in this paper is organizational commitment, which is an employee's willingness to stay at a company or organization (Kanter, 1968). Many aspects of a job or organization can impact organizational commitment. This paper focuses on aspects of the job as outlined in Hackman and Oldham's (1975) Job Characteristic Model (JCM). Aspects of the job have been found to be related to organizational commitment (Mowday, Porter, \& Steers, 1982); however, the tasks of a job are not the only element employees will experience during their employment. A manager plays a critical role in how the design of the job is implemented by providing resources to do the job and offering additional feedback and support. It is believed that the employee-to-manager relationship, leader-member exchange (LMX), moderates the association between job characteristics and organizational commitment. This study examined the moderating effect of LMX on the relationship between job characteristics and organizational commitment. 


\section{History of Organizational Commitment}

Many labels have been given to organizational commitment. Kanter (1968) was one of the first researchers of organizational commitment and originally divided the concept into two: cognitive continuance commitment, the conscious decision to remain at the organization, and cohesion commitment, an attachment to the organization. Hrebiniak and Alutto (1972) established a similar idea of commitment, but their division was calculative and moral commitment. Thus, the concept of the conscious act of remaining at an organization based on an evaluation had developed from a conscious decision to stay (Kanter, 1968) to a calculated comparison of the assets (i.e. salary, comfort, location) gained or lost when staying or leaving. Mowday et al. (1982) expanded on these themes, categorizing organizational commitment as behavioral commitment, a process in which the individual remains at the organization due to the calculative costs of leaving, and attitudinal commitment, which is a mindset based on the congruence between an individual's and an organization's values and goals. These themes were accepted as the broad categories of organizational commitment from the 1970s to 1980 s.

The first theme of commitment, behavioral commitment, is defined as the continuation of an action because of recognition of what would be lost if the continuation were to be terminated (Becker, 1960; Kanter 1968; Stebbins, 1970). Some things that could be lost if employment were terminated are salary, bonuses, location, and benefits. Employees' comparison of what could be lost and gained by switching organizations can occur through subconscious (Salancik, 1977) or deliberate (Kanter, 1968; Mowday et al., 1984) evaluations. Behavioral commitment's calculative nature is reflective of Vroom's 
(1964) expectancy theory. It posits that individuals will act in a certain way because of the expected results of that behavior. These expected results come from a personal cognitive assessment of behavior and consequential results. Thus, there may be an interaction between two parties that involves an analysis of the exchange.

The second theme of commitment, attitudinal commitment, is defined as affective attachment to the goals and values of the organization (Buchanan, 1974), which leads to a strong attitudinal identification and involvement with the organization (Mowday et al., 1979; Porter et al., 1976). There are not many theories associated with attitudinal commitment, but Eisenberger, Huntington, Hutchison, and Sowa's (1986) exchange ideology shines some light on attitudinal commitment. They describe the norm of reciprocity, an innate occurrence that people will react favorably with others by returning perceived benefits or respond with hostility if they perceive harm. Therefore, an individual feels an attachment and identification with an organization when he or she perceive benefits, progression to similar goals, or support in similar values from the organization.

However, Fishbein and Ajzen (1975) proposed a vastly unexplored definition of organizational commitment. They believed that another attitudinal theme existed in which employees remain committed because of loyalty or duty, and stay because it is the 'right' thing to do. Other researchers supported this new theme, showing that it was a significant belief regardless of external factors such as other job offers or perceived organizational support (Marsh \& Mannari, 1977). Some researchers went further to assert that this morally right attitude creates an internalized pressure to meet 
organizational goals and interests (Wiener, 1982 as stated in Meyer \& Allen, 1991). This internalized pressure to stay and perform convinces the employee to remain at an organization even if he or she is not happy or satisfied.

Researchers remained in conceptual silos, only investigating organizational commitment through the lens of behavioral or attitudinal commitment until the late 1970s. This separation caused Steers (1977) and Mowday et al. (1982) to call for a more complex model that explains the dynamics between and within the categories of organizational commitment and how the process of becoming committed to an organization influences employee outcomes. This call was answered by Meyer and Allen (1991), who used earlier definitions of commitment, including those surrounding affective attachment, obligation, and perceived costs, to create their three-component model of commitment.

The three-component model defines organizational commitment as a psychological state between the employee and the organization in which the employee identifies with the organization. This identification leads the employee to remain at the organization. This state is broken down into three dimensions: continuance, normative, and affective commitment.

Continuance commitment is a conscious or subconscious behavioral analysis of what would be lost if employment were terminated. The employee observes the current benefits, or side bets (pay, benefits, stress, location, timing, environment, etc.) and external obligations such as mortgage, family responsibilities, proximity to day care, and flexibility in schedule. These elements are calculated and compared to other job offers or 
to not having a job at all. If the side bets of a new opportunity outweigh the benefits of the current situation, the employee will no longer be committed and will leave the organization. Rather than having a desire to stay, continuance committed employees stay to reduce the risk of loss. In this type of commitment, employees feel that their choice to stay or leave is controlled by external forces. Employees may feel pressure to satisfy the minimum job requirements, but they stay because they believe they have little choice (Meyer \& Allen, 2004). Thus, their commitment is contingent upon there not being a better offer, and once that offer appears, their commitment decreases to the point that the employee will leave the organization.

Normative commitment is an attitudinal connection of obligation towards the organization. The employee feels obligated because the organization has given him or her so much that he or she feels a sense of duty and loyalty, and that staying is 'the right thing to do'. This obligation is enacted when the employee receives such things as pay, opportunity, benefits, and growth. Due to the perceived investment from the organization in the employee, the employee responds by investing time, energy, and work in the organization (Meyer \& Allen, 1991). This form of commitment engages the norm of reciprocity discussed earlier, producing a connection based on an exchange. Employees may be committed, but they will only put in the same amount of effort as they believe the organization is investing in them. Once the employee perceives a reduction in the organization's investment, his or her loyalty will diminish. This reduction can result from the employee not feeling supported, appreciated, or receiving a raise. Regardless of the 
reason, once the exchange is perceived as one-sided, the employee's level of commitment will decrease.

Affective commitment is an emotional attachment to the organization. Employees perceive the similarities between the organization's and their own morals and values, leading them to identify with the organization. This identification increases the employees' involvement and engagement, intensifying the emotional bond. Affective commitment represents a plethora of thoughts regarding expectations, equity, and comparisons that can be used and measured across situations (Meyer \& Allen, 1991). Affective commitment produces the strongest tie between the employee and organization because it is a sentimental, personal connection to the organization. To discontinue employment, the employee would have to perceive a drastic change in the organization's values, goals and morals or establish a stronger personal tie to another organization - a rare occurrence.

The three-component model categorizes commitment into three dimensions that can influence behaviors and attitudes both interactively and independently. This enhancement improves upon previous research that separated commitment into types, making them mutually exclusive (Meyer \& Allen, 1991). The three-component model underwent critical review in subsequent years that questioned the correlations among the components, especially between normative commitment and affective commitment (e.g. Meyer \& Allen, 1991; Morrow, 1983; Mowday, Porter, \& Steers, 1982; Reichers, 1985). The relationship between normative commitment and affective commitment was examined because some believed there was overlap between the two constructs. 
However, researchers found that each category of commitment was independently related to the proposed antecedents of commitment, which provides consistent affirmation of its measurement of three separate constructs (e.g. Meyer, Allen \& Smith, 1993). Therefore, this study used the Meyer and Allen (1991) three-component model as its definition and measurement of organizational commitment.

\section{The Value of Organizational Commitment}

Why should industries care about organizational commitment? Overall, organizational commitment has been found to be extremely beneficial to organizations as it leads to positive behavioral and attitudinal work outcomes. In regards to behavioral work outcomes, organizational commitment has been found to be related to increased performance, initiative taking, work efforts, decreased turnover and absenteeism (i.e. Jones, 2006; Luchak \& Gellatly, 2007; Mowday et al., 1982; Meyer \& Allen, 1997; Srivastava \& Dhar, 2016). Committed employees are more productive and effective at work and are less likely to be absent or leave their jobs. In the realm of attitudinal work outcomes, organizational commitment is related to higher job satisfaction, selfdirectedness, and motivation (Buch, 2015; Srivastava \& Dhar, 2016; Wallace, 1995) as well as lower turnover intentions (Meyer \&Allen, 1991). Work attitudes in committed employees are better because employees are motivated to do their job; they come to work happy and are willing to put in more effort. In addition, employees do not require as much supervision because they take initiative and direct themselves. These consequences of organizational commitment increase companies' profit margins because employees are productive and do not engage in behaviors that cost the company money, such as 
absenteeism. In addition, commitment leads to less turnover, so companies spend less money on recruiting, onboarding, and training new employees.

Overall organizational commitment has been found to be related to work outcomes; however, the three dimensions of organizational commitment differ in their individual relations to these outcomes. Researchers have found affective and normative commitment to be positively related to job satisfaction, effective use of time, and negatively related to intentions to leave, whereas continuance commitment is not related to these work outcomes (e.g. Luchak \& Gellatly, 2007). This difference in relationships may be due to the causes of the types of commitment. Specifically, affective and normative commitment are attitudinal attachments to the organization, whereas continuance commitment is a behavioral reaction to an assessment of current and future situations. This differentiation could cause the subsequent relationship to differ in strength. Those who experience continuance commitment may only be motivated to complete the minimum job requirements and are dissatisfied with their jobs. Therefore, employees may not use their time effectively and have intentions to leave, but have not actually ended their employment because a better option does not exist yet. Therefore, the relationship between continuance commitment and work outcomes would be weaker in comparison to the other dimensions of commitment that produce an internal drive to remain in the organization and establish connection between employee and organization.

Researchers have also found that affective commitment has a more reliable and greater relationship with work outcomes compared to normative commitment (e.g. Luchak \& Gellatly, 2007; Meyer, Allen, \& Smith, 1993). This difference in strength may 
occur because affective commitment motivates employees through an internal drive that leads to the desire to fulfill the maximum level of accomplishment in their role (Luchak $\&$ Gellatly, 2007). Therefore, affectively committed employees put in more effort, prioritize their time to accomplish more tasks, and go above and beyond the job requirements. Employees who experience affective commitment exert more effort, use their time better and go beyond job requirements more than normative commitment, and employees who experience normative committed exert this effort, use their time, and go above more than employees who experience continuance commitment. Affectively committed employees' stronger ties to the organization produce stronger relationships with positive work outcomes. Luchak and Gellatly (2007) suggest that even though the dimensions are important in developing organizational commitment, the dimensions are not equal in their relation to other variables.

\section{Predictors of Organizational Commitment}

Now the question is, how can companies increase or predict organizational commitment? Steers (1977) categorized antecedents of affective commitment into three groups: personal characteristics (age, educational level, and gender), organizational characteristics (structure, policies, and rules), work experiences (social factors and attitudes that influence psychological attachment) and job- or role-related characteristics (job characteristics, job scope or challenge, role conflict, and role clarity). Mowday et al. (1982) added a fourth category of structural characteristics (formalization, decentralization of authority). The next section will describe these categories and the associated variables in how they are related to organizational commitment. 
Personal characteristics. Personal characteristics have been examined in regards to demographics (i. e. age, gender, level of education). D’Amato and Herzfeldt (2008) found that age was related to organizational commitment, such that younger generations (i.e. born 1960 and after) showed lower organizational commitment than older generations (i.e. born 1946-1959). Gender has been found to be related to commitment, with women being more committed than men (Mowday, 1982). This relation may be due to barriers women must overcome to enter the organization, therefore creating a stronger tie to the organization (Salancik, 1977). Level of education has been shown to be inversely related to commitment, with those with higher education being less committed compared to those with less education (Mowday, 1982). This may be because those with higher education may have higher expectations that an organization cannot meet. However, other research has found contradictory findings. Therefore, this relationship is mixed because of a lack of distinction between job and organizational commitment, resulting in plausible confounding variables (Mowday, 1982).

Organizational structural characteristics. Organizational characteristics, such as the structure, policies, and rules of an organization, also impact an employee's commitment. Specifically, the decentralization of decision-making and authority has been found to be related to high organizational commitment (Meyer \& Allen, 1991). This may occur because less formalization increases autonomy, which is known to lead to higher organizational commitment.

Overall organizational dependability, the perceived extent the organization could be counted upon to support employees' interests, has also been related to commitment 
(Meyer \& Allen, 1991; Mowday et al., 1982). Employees who believed their organization invested in them, had their best interest at heart, and if the organization had a steady revenue stream were more committed than employees who did not feel they had dependable organizations.

Work experiences. Work experiences have been extensively examined as predictors of commitment. Examples of work experiences include personal preferences being fulfilled, increased income, engagement with coworkers, and how the organization and leaders provide support. For personal preference, employees will be committed if they feel they are important to the organization, their expectations are met, and they perceive equity in pay and reward distribution (Meyer \& Allen, 1991; Mowday et al., 1982). Increased income has been found to be associated with reduced affective commitment but high continuance commitment (Gunlu, Aksarayli, \& Percin, 2010). This relationship may be due to income being an extrinsic reward that does not elicit an internal identification and attachment to the organization, and can be perceived as a poor attempt to make up for other grievances. However, it can also be viewed as an investment in others, which would incite further exchange relationships because of felt obligation. In regards to engagement with coworkers, employees who connect with coworkers through social involvement in and outside of work have been found to be more committed (Wallace, 1995). This relation occurs because the connection with coworkers adds an additional resource, side bet, or perceived investment.

Organizational support is positively related with commitment. One study found that the more employees felt the organization supported them, the more they were committed 
overall; more specifically, organizational support had the strongest relation to affective commitment (Wallace, 1995). In addition, organizations that provide career mobility opportunities produce lower scores for normative and continuance commitment among employees; but employees who preferred these opportunities felt more emotionally attached to the organization (Joao \& Coetzee, 2012). Thus, organizations that show support increase employee's overall commitment, but providing career mobility opportunities only increases affective commitment in employees who prefer these opportunities; for the rest, these opportunities may decrease their normative and continuance commitment. This negative relationship may be because there are opportunities, but the organization has not invested in the employee to fully promote them. The opportunity is just out of reach for the employee, not increasing the current pay, benefit, or status. Therefore, employees do not feel an obligation or view their current situation as that valuable because they did not receive the investment or actual increase in value. In fact, employees may feel less obligated because they have a chance to receive more - such as a promotion, but have not received the actual promotion yet. Lastly, regarding leader support, supervisor consideration has been found to be positively related to affective commitment (Meyer \& Allen, 1991).

In summary, these findings suggest that although jobs and organizations may have defined structures and policies, employees interpret and experience these elements differently. Thus, employees work experiences are a separate but still powerful factor in the prediction of organizational commitment. 
Job/role-related characteristics. Job or role characteristics are elements outlined in a job description. Role characteristics are experiences that arise from a job, whereas job characteristics are the fundamentals that outline what employees do daily and are the building blocks of job design. Role characteristics include role conflict and clarity. Role conflict, a position having incompatible expectations or roles, has been found to be inversely related to commitment such that the higher the conflict, the lower the employee's commitment (Mowday et al., 1982). For example, the more a role forces an employee to be detail-oriented but also deliver results very quickly, the less the employee will be committed. Role clarity is positively related to affective commitment (Meyer \& Allen, 1991). Therefore, the more specifically expectations, deliverables, and steps to reach goals are outlined, the higher the employee's affective commitment.

Job characteristics include the aspects of the actual job and the variety of those aspects. Aspects of the actual job such as autonomy, responsibility and challenging tasks have been found to be related to organizational commitment, such that the more challenging a task is, in which the employee is independently accountable for the results, the higher the organizational commitment (Hsu \& Liao, 2016). In regards to job scope, which represents the range of activities, duties, or responsibilities within a position, past research has found that the larger the job scope, the higher the commitment (Mowday et al., 1979). This may be due to the theory of social exchange, which states that the more employees are given activities, duties, and responsibility, the more they feel they owe the company their time, effort, and commitment. The company is trusting them with more 
responsibility, so the employees return the favor by being more committed (Mowday et al., 1982).

These predictors play an important role in encouraging organizational commitment. It is this last category of predictors of organizational commitment, job characteristics, that researchers have been focusing on in recent years (e.g. Hsu \& Liao, 2016; Jackson, Meyer, \& Wang, 2013). One goal of this focus is to understand what fundamentals are needed in a job to create organizational commitment. Specific challenges, level of autonomy, and range of tasks within jobs have been studied to observe the impact on organizational commitment. In recent years, most researchers have used the job characteristics outlined in the Job Characteristics Model (Hackman \& Oldham, 1976). The model is described in detail in the next section.

\section{The Job Characteristics}

Many theories have tried to understand how job design and its characteristics impact employees. Job design was originally defined as opportunities and restraints designed into tasks and responsibilities that affected the accomplishments and experiences of an employee's work (Hackman \& Oldham, 1980). One of the most influential theories behind job design was Herzberg, Mausner, and Snyderman's (1959) two-factor theory called Motivation-Hygiene theory. On the one hand, this theory posits that intrinsic factors derived from work are what determine employee satisfaction. These factors, or motivators (recognition, achievement, responsibility, advancement, personal growth in competence), motivate employees to perform better. On the other hand, extrinsic factors 
from the work itself, also referred to as hygiene factors (company policies, supervisory practices, pay plans, and working conditions) lead to dissatisfaction.

The socio-technical systems theory by Emery and Trist (1960) broadened the scope to recognize interdependencies between technical aspects of work (duties, activities, skills) and the social environment in which the work is completed (leader, coworker, organizational support (Hackman \& Oldham, 1976). Rather than view job design through two separate lenses, socio-technical systems theory examined how two aspects of a job, the fundamentals and the psychological aspect, could independently and interactively lead to work outcomes.

The motivation-hygiene and socio-technical systems theories both focus on the physical and psychological aspects of a job. The motivation-hygiene theory has policies/practices and responsibility/achievement, whereas socio-technical theory has duties/activities and leader/coworker support. However, these theories failed to produce reliable results, failed to outline the process in which employees were impacted, or provide reasons why these interactions occurred. When Hackman and Oldham (1976) developed their job design theory, they developed research similar to the aforementioned physical and psychological focus from the motivation-hygiene socio technical theories, but they merged the aspects of these two theories. Their theory combines the physical duties activities and practices with the psychological effect of support, responsibility, and achievement, to produce what is needed for a motivating job. Hackman and Oldham developed their theory into a measurable, reliable model that describes how aspects of a 
job engage innate psychological states. This model is the Job Characteristics Model (Hackman \& Oldham, 1976).

The Job Characteristics Model posits that when job design is high on five core job dimensions and three psychological states, employees are engaged and experience positive work outcomes. As seen in Figure 1, there are three psychological states: experienced meaningfulness of the work, responsibility for the outcomes of the work, and knowledge of the results of the work activities. These psychological states act as a mechanism for the job characteristics to result in positive work outcomes (Hackman \& Oldham, 1975). Experienced meaningfulness of the work is the degree to which the employee perceives the job as meaningful, valuable and worthwhile. Experienced responsibility for work outcomes is when employees feel personally accountable for the results of the tasks they complete. Lastly, knowledge of results is when the employee continuously knows and understands how effectively he or she is performing the job (Hackman \& Oldham, 1976). These three psychological states lead to positive work outcomes because the employee knows he or she has personally performed well on a task he or she cares about, thus incentivizing the employee to continue to try to perform well in the future. 


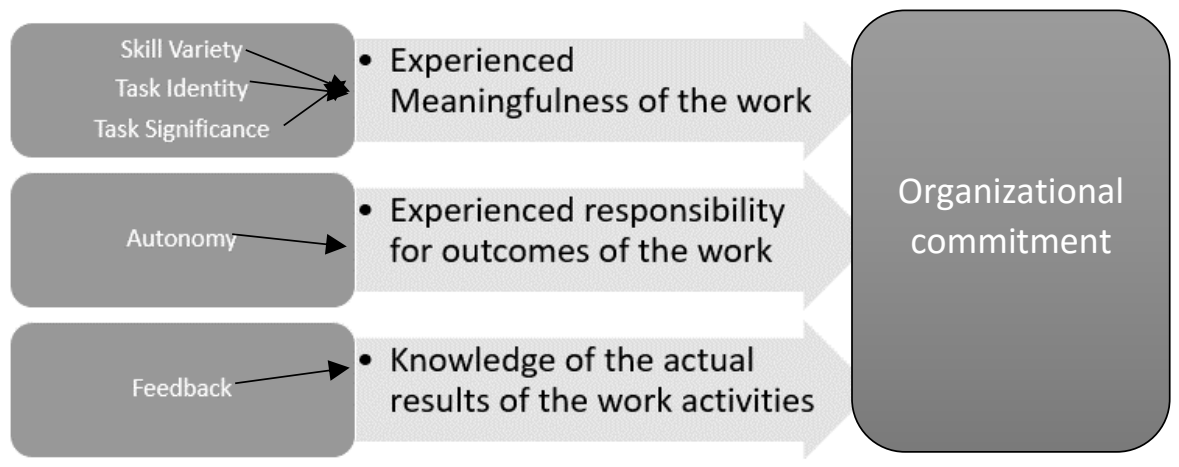

Figure 1. Job characteristic model by dimension

The three psychological states occur because of five core job dimensions: skill variety, task identity, task significance, autonomy, and feedback. Skill variety is the degree to which a job requires a variety of tasks and activities to complete the work, all of which involve different skills and talents. Tasks that require several skills, talents, or knowledge challenge employees to stretch their skills and abilities, leading to the activities being meaningful. This tie between challenging tasks and meaningfulness remains true even if the task is objectively not of great significance or importance.

Task identity is when the tasks are an identifiable part of a whole job; that the work an employee does is part of a larger picture and something bigger than the single task. Task identity occurs when the employee works on a task from beginning to end with a visible outcome, completing a "whole" job. When employees can identify the piece of work they completed, they perceive the work as more meaningful than if they only completed a small part of the job.

Task significance relates to the job having a substantial impact on the lives or work of other people, regardless of the scope of the impact (immediate organization vs. external 
environment). When employees comprehend the effect of their work on others, they naturally view the work as being more meaningful.

Autonomy is the degree to which the job provides freedom, independence, and discretion in scheduling the work and in determining the procedures used. The independent tasks interact with the employee's own efforts, initiative, and decisionmaking rather than relying on others to tell the employee what to do. With the freedom to decide the place and pace of the job the employee feels a responsibility for the success or failure that result from his or her work.

Feedback is the degree to which work activities give the employee direct and clear information regarding the performance of his or her work. It is important to note that it is the job itself, rather than a manager, that provides feedback on how the employee is performing. For example, when a code is accepted without errors and all features work correctly, the task itself is the feedback that lets the coders know they are performing effectively.

The five core job dimensions are grouped with one another and through their interaction relate to the three psychological states. First, to initiate experienced meaningfulness, skill variety, task identity, task significance must be high because when combined these core job dimensions challenge the employee to go above and beyond the job requirements, become more engaged with their tasks they are completing, and be motivated to do work well. This challenge is associated with overcoming obstacles, extra effort, and a sense of accomplishment after completion, which results in an employee perceiving the work as meaningful, valuable and worthwhile. To stimulate experienced 
responsibility, autonomy must be high because the freedom in determining the way in which the work is completed makes the employee feel accountable for the task itself. Lastly, to activate the psychological state of knowledge of results, the feedback dimension must be high, because feedback, through giving information on the effectiveness of the work, enables employees to understand how they are performing.

\section{Job Characteristics and Organizational Commitment}

Job characteristics been researched in relation to numerous work outcomes.

However, this study will focus solely on the relation of the core job dimensions outlined in the Job Characteristics Model to organizational commitment. In their meta-analytic summary, Humphrey, Nahrgang, and Morgeson (2007) found that the five core job dimensions explained $40 \%$ of the variance in organizational commitment. Prior researchers find that high core job dimensions lead to overall organizational commitment (e.g. Pentareddy \& Suganthi, 2015). Similarly, research has found that this relationship exists regardless of cultural differences (Joo, 2010). For example, in a Taiwanese study involving banking and service and manufacturing industries, job characteristics were found to significantly impact overall organizational commitment (Chang \& Lee, 2006). Hsu and Liao (2016) found that jobs with high levels of all job characteristic dimension were positively related to organizational commitment. Madi, Abu-Jarad, and Alqahtani (2012) found that the more skill variety, task significance, feedback, autonomy, and task identity, the more the employee was committed to the organization. Similarly, Ozturk, Hancer, and Young (2014) found a direct relation between high core job dimensions and higher organizational commitment. 
The entire JCM also directly influences specific dimensions of organizational commitment. Madi et al. (2012) and Ozturk et al. (2014) found a relationship between high core job dimensions and high levels of affective commitment. When Pentareddy and Suganthi (2015) found similar results, they highlighted that to build affective commitment, jobs should be filled with challenging activities, opportunities to utilize many different skills, and whole tasks that had a potential to make a difference to the business. There should also be feedback mechanisms built into the job, as this mechanism helps employees improve and appreciate their work, and further lead to affective commitment. (Pentareddy \& Suganthi, 2015). Thus, the entire JCM with or without the psychological states is positively related to high affective commitment.

However, not all job characteristics influence organizational commitment equally. O'Reilly, Parlette and Bloom (1980) found that employees who perceived the job characteristics of autonomy, skill variety, task identity and feedback as highly motivational were affectively committed. Hsu and Liao (2016) found that task significance, autonomy, and feedback influenced organizational commitment, but task identity did not. They believed this could be due to managers enhancing task significance, autonomy, and feedback to build organizational commitment. Overall, compared to the other dimensions, the core dimension of job autonomy seems to be the most important in leading to positive organizational commitment (Hsu \& Liao, 2016). On the other hand, task variety has the least impact on organizational commitment compared to the other job dimensions (Abbott, Boyd, \& Miles, 2006). 
Job characteristics have been repeatedly investigated and related positively with organizational commitment. However, research has also investigated factors that could affect the relationship between the core job dimensions and organizational commitment. The next section in this paper will summarize the specific variable of leadership and how it moderates the relationship between job characteristics and organizational commitment.

\section{Moderating Job Characteristics: Leadership}

Recent researchers have included other variables that may enhance the positive effects of the JCM (Piccolo, Greenbaum, Hartog \& Folger, 2010). Parker, Wall, and Cordery (2001) asserted that just considering traditional work characteristics was outdated in the world of the modern work context, and other variables like leadership, management style and support needed to be considered in addition to the core job dimensions of JCM when predicting behavioral and attitudinal work outcomes.

Researchers have considered management style in combination with the core job dimensions because of the leader's ability to increase the perception of and presence of task significance, autonomy, and feedback. Some researchers have even stated that in studying the relationship between job characteristics and organizational commitment, leadership could be a key factor because managers can enhance task significance, autonomy, and feedback to build organizational commitment (Hsu \& Liao, 2016). Selfdetermination theory (Ryan \& Deci, 2000) supports this investigation as it recognizes the role of a leader in creating an environment that promotes feelings of competence, autonomy, and relatedness, which relates to the psychological states of the JCM. Higher 
feelings of competence, autonomy, and relatedness in turn lead to higher organizational commitment.

There has been research considering specific types of leadership styles moderating the relationship between core job dimensions and organizational commitment. For example, Pentareddy and Suganthi (2015) investigated the moderating effect of leadership complexity on the relationship between job characteristics and organizational commitment. Leadership complexity is the ability to embody paradoxical roles to deal with competing demands. Leaders who are complex can adjust their reactions, priorities, and approach to solve problems when they arise. Leaders who are complex are also adept at setting a vision, adapting to the work or employees' needs, and ensuring deadlines are met.

Leader complexity was found to moderate the positive relationship between the JCM and organizational commitment. The more the leader could handle the complexity of competing demands, the stronger the positive relationship between JCM and organizational commitment (Pentareddy \& Suganthi, 2015). This is because the leader is skilled in multiple dimensions of being a manager, adaptability, communication, visions setting. Thus, the leader allows the employee to operate with more freedom, enables the employee can communicate how the job is part of a vision and draw connections on how his or her job impacts other employees. This enhances task significance and autonomy, which have been shown to be positively correlated to organizational commitment. 


\section{Leader-Member Exchange (LMX)}

There have been investigations into leadership styles' influence on the relationship between core job dimensions and organizational commitment (e.g. Buch, 2015; Pentareddy \& Suganthi, 2015; Portoghese, Galletta, Battistelli, Leiter, 2014). However, there has not been research investigating the influence of Leader-Member Exchange on all the core job dimensions of the JCM in relation to all three dimensions of organizational commitment.

Leader-Member Exchange (LMX) is the quality of the exchange relationship between employees and their supervisors (Liden, Sparrowe, \& Wayne, 1997). The leader inherently develops varying quality relationships with each employee, creating subsequent in-and-out groups. The quality of LMX ranges from low-quality to highquality. Based on Blau's (1964) conceptualization of social and economic exchanges, the literature has commonly referred to high-quality LMX relationships as social exchange relationships in which more trust, small talk, and friendly communication exists. These exchanges can still exist in low-quality LMX relationships, but they are limited. Lowquality LMX relationships have been commonly referred to as economic exchange relationships in which the transactions are more centered on business, are less friendly, and the interactions with the manager occur less frequently. (Buch, 2015).

In low-quality LMX relationships, there is a limited amount of time and information exchanged between the employee and the leader. These relationships are impersonal and economic, and based on contractual interactions. Leaders provide employees with no more than the resources needed to perform, and employees fulfill only the basic job 
requirements (Buch, 2015). This bare minimum exchange rarely results in the employee receiving challenging tasks and skill development opportunities. In addition, the employee does not experience a sense of personal choice (Graves \& Luciano, 2013). In fact, low-quality LMX relationships are characterized by inattention, task orientation and mistrust (Liu, Cai, Li, Shi, \& Fang, 2013). This type of relationship between leader and employee qualifies the employee as an 'out' group member.

In contrast, high-quality LMX relationships are characterized by mutual respect, trust, and obligation between the leader and the employee. This relationship is established from the beginning when employees' competence and performance convinces leaders to give them additional responsibility; from there, an exchange of influence, support, and resources are maintained (Graves \& Luciano, 2013). High-quality LMX relationships also come with higher attention and benefits, which lead to more frequent promotions, formal/informal rewards, and higher understanding (Liu et al., 2013). This relationship would qualify the employee as an 'in' group member.

The quality of LMX can consciously or subconsciously impact the amount of resources, communication, trust, and projects an employee is given. Even if a job is designed to have high core job dimensions (i.e., feedback, autonomy, task identity, skill variety, and task significance), a manager's leadership style can detract from the job dimensions by being controlling, keeping significant and challenging projects to themselves, and not offering feedback. This may cause an employee to no longer be committed to the organization. This situation may be the source of the cultural colloquium, “you leave a manager; you don’t leave a company" (Lipman, 2015). The 
colloquium may be well known, but the extent of the leader's impact on job characteristics and organizational commitment is not known. It is this line of research this study addresses.

Even though LMX has not been used as a moderator of the all of the core job dimensions and organizational commitment relationship, it has been used to moderate a similar relationship according to work by Portoghese et al. (2014). They investigated the moderating effect of LMX on the relationship between job characteristics and job satisfaction and turnover intention at the group level. Portoghese et al. (2014) found that LMX moderated the relationship between job characteristics and job satisfaction. Specifically, they found that high LMX enhanced the effects of autonomy, task variety, task significance, task identity on job satisfaction.

Although Portoghese et al. (2014) explored the interaction between LMX and job characteristics, they did not investigate the moderating effect of LMX on the core job dimensions of the JCM. In addition, they stated that one of their limitations was ignoring other outcome variables such as organizational commitment. Given the lack of investigation into the moderating effect of LMX on the relationship between the core job dimensions and organizational commitment, more research is needed. This lack of research is the gap this paper intends to address.

As outlined in Figure 2, it is hypothesized that every core job dimension is uniquely and independently related to each dimension of organizational commitment. The second hypothesis is that LMX will moderate the relationship between the core job dimensions of the JCM and organizational commitment. Specifically, it is hypothesized that high- 
quality LMX relationships will strengthen the relationships between the core job dimensions and organizational commitment. In contrast, low-quality LMX relationships will weaken the relationship between the core job dimensions and organizational commitment. This moderation occurs because high-quality LMX possesses the nature of the leader giving the employee more responsibility, more projects, trust, attention, which can be categorized in the core job dimensions of task significance, skill variety, task identity, autonomy, and feedback. All of which elicit organizational commitment from the employee.

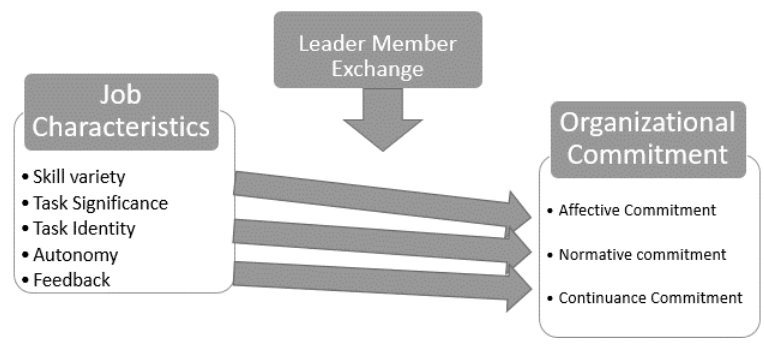

Figure 2. The moderation effect of LMX on job characteristics and organizational commitment

The third hypothesis is an exploration hypothesis in which an investigation will occur for the impact of LMX on the relationship between the core job dimensions and organizational commitment will differ between the three components of organizational commitment. I wish to explore if certain core job dimensions are impacted differently by LMX and how this effect influences organizational commitment as a whole or per dimension. For example, LMX may only impact autonomy, feedback and task identity; which would lead to greater organizational commitment, specifically affective and continuance commitment. This paper has outlined how an organization can design a 
perfectly motivating job that results in a committed employee, there is still a cultural colloquium that employees leave their managers not their job. This colloquium is why this study is being conducted, to explore the influence of a manager on the relationship between job characteristics and organizational commitment. 


\section{Method}

\section{Participants}

The participants in this study were recruited through the researcher's personal and professional network. A total of 266 individuals participated in this survey. Out of the 266 , five responses were removed because they had never had a manager in a job currently or in the past, and 40 participants were removed due to insufficient data. Thus, the final sample consisted of 221 participants.

The final sample included 156 females and 65 males (Table 1). The majority of the respondents were between the age of 25-34 years old (39.4\%) and 18-24 years old (29.4\%). Most participants' employment status were full-time (73.3\%), followed by parttime $(20.4 \%)$. In regards to the length participants worked at their organization, $25.3 \%$ worked at their organization for 1-3 years, $24.0 \%$ of participants worked at their organization for 6 months - 1 year, $17.2 \%$ of participants worked at their organization for more than 10 years, $16.7 \%$ worked at their organization for less than 6 months, $8.6 \%$ of participants worked at their organization for 3-5 years, and $8.1 \%$ of participants worked at their organization for 5-10 years. Lastly, the length of time with the participant's manager was surveyed and $27.1 \%$ of participants had been with their manager less than 6 months, $27.1 \%$ of participants worked with their managers 6 months -1 year, $26.2 \%$ of participants had been with their manager for 1-3 years, $8.6 \%$ of participants had been with their manager for 3-5 years, $6.8 \%$ of participants had been with their manager for 510 years, and $4.1 \%$ of participants had been with their manager for more than 10 years. 
Table 1

Demographic Characteristics of Participants $(N=221)$

\begin{tabular}{lrr}
\hline \multicolumn{1}{c}{ Variable } & $\mathrm{n}$ & \multicolumn{1}{c}{$\%$} \\
\hline Employment status & & \\
Employed Full-Time & 162 & $73.3 \%$ \\
Employed Part-Time & 45 & $20.4 \%$ \\
Self-Employed & 1 & $.5 \%$ \\
Unemployed & 6 & $2.7 \%$ \\
Retired & 7 & $3.2 \%$
\end{tabular}

Gender

Male

$65 \quad 29.4 \%$

Female

$156 \quad 70.6 \%$

Age

18 - 24 years old

$66 \quad 29.9 \%$

25 - 34 years old

$87 \quad 39.4 \%$

35 - 44 years old

$25 \quad 11.3 \%$

45 - 54 years old

$28 \quad 12.7 \%$

55 - 64 years old

$9 \quad 4.1 \%$

65 - 74 years old

$3 \quad 1.4 \%$

75 years or older

$3 \quad 1.4 \%$

Length at current

organization

Less than 6 months $\quad 37 \quad 16.7 \%$

6 months - 1 year $\quad 53 \quad 24.0 \%$

$1-3$ years

$56 \quad 25.3 \%$

3 - 5 years

$19 \quad 8.6 \%$

5 - 10 years

$18 \quad 8.1 \%$

More than 10 years

$38 \quad 17.2 \%$

Length with your manager

Less than 6 months

$60 \quad 27.1 \%$

6 months - 1 year

$60 \quad 27.1 \%$

$1-3$ years

$58 \quad 26.2 \%$

3 - 5 years

$19 \quad 8.6 \%$

5 - 10 years

$15 \quad 6.8 \%$

More than 10 years

$9 \quad 4.1 \%$ 


\section{Measures}

Job characteristics. Job characteristics were the elements of a how a job was designed, specifically, skill variety, task significance, task identity, autonomy, and feedback. Job characteristics were measured with Hackman and Oldham's (1974) Job Diagnostic Survey. However, for this study, the survey was adapted from 21 items to 15 items. This adapted survey consisted of three items per dimensions, such as "The job gives me chances to use my personal initiative or judgments in carrying out the work" and "The job was quite simple and repetitive." The response format for the survey items consisted of a 7-point Likert scale of agreement $(1=$ Strongly Disagree, $7=$ Strongly Agree). Participants' responses were averaged to create an overall score ranging from 1 to 7 , with higher scores indicating the respondents experienced high levels of skill variety, task identity, task significance, autonomy, and feedback. Cronbach $\alpha$ was .71, indicating high reliability of the scale.

Leader-member exchange. Leader-member exchange, LMX, is the relationship between an employee and manager that can range from low quality to high quality, based on mutual trust and respect. LMX was measured with an adapted survey of Liden's (1997) LMX-7 survey. This adapted survey condensed the seven items into five items, such as "My manager recognizes my potential" and "I would defend my manager if they were not there to do so themselves." The response format for the survey items consisted of a 7-point Likert scale of agreement ( $1=$ Strongly Disagree, $7=$ Strongly Agree $)$. For each participant, his or her response was averaged to create an overall score ranging from 1 to 7 , with higher scores indicating a high-quality relationship with a manager; which 
consists of mutual trust and respect. Cronbach $\alpha$ was .87 , indicating high reliability of the scale.

Organizational commitment. Organizational commitment is the willingness to remain at the organization and is categorized by three dimensions: affective, normative, and continuance commitment. Affective commitment is an attitudinal attachment to the organization based on shared beliefs and values. Normative commitment is attitudinal obligation to the organization based on duty and loyalty. Finally, continuance commitment is a behavioral comparison of the current employment against another employment opportunity and the decision to remain at the organization is dependent on which situation is more beneficial (Meyer, Allen, \& Smith; 1993). The dimensions of organizational commitment were measured with an adapted version of the Meyer, Allen, and Smith's (1993) The Affective, Continuance and Normative Organizational and Occupational Commitment Scales. The survey was reduced from 6 items per dimension to three items each, resulting in nine items total. The response format for the survey items consisted of a 7-point Likert scale of agreement $(1=$ Strongly Disagree, $7=$ Strongly Agree). For each participant, responses were averaged to create an overall score ranging from 1 to 7 , with higher scores indicating the respondents experienced high levels of all type of commitment. Cronbach $\alpha$ for affective commitment was .66, for normative it was .67 , and for continuance commitment it was .56.

\section{Procedure}

The external survey vendor Qualtrics was selected as the method of survey distribution. All participants received an email or saw a post on Facebook inviting them 
to take the survey, and were provided a link to the vendor's website. The survey duration was two weeks, and all surveys were completed online at various times. Upon accessing the survey, respondents were shown a message explaining the purpose and goals of the survey, including using their responses to identify opportunities for improvement within companies. The message also reminded respondents of the confidentiality of their responses. There were no restrictions on who was invited to participate in the survey. Once participants consented and clicked on the start survey button they were brought to the first question of the survey. The question asked if the respondent had ever had a job with a manager. Those who answered no were exited out of the survey as their answers would not be relevant for a study regarding the influence of managers.

All eligible participants were taken to the next page of the survey. They were greeted with a message that all questions should be answered based on the participant's current occupation and manager. The instructions once again reminded participants of their anonymity. Underneath those instructions were 34 items; five of these items were measuring LMX. Nine of these items related to the three dimensions of organizational commitment, 15 of the items related to the five core job dimensions of the Job Characteristics Model. Lastly, participants were asked to respond to five demographic questions related to their employment status, gender, age, length of employment at the organization, and length of time with the current manager. Once the participants answered the demographic questions, they were directed to the end of the survey. Once respondents finished the survey, they were informed that responses had been recorded, thanked for their time and advised that if they had any questions to contact the researcher. 
Participants answered the questions at their own pace. All survey submissions were collected when the participants pressed the submit button at the end of the survey. After the survey completion date, the data were collected and stored in a secured database. Any personally identifying information was not collected to ensure confidentiality of the participants' responses. The collected data were then prepared for analysis using the SPSS v. 22 software package. 


\section{Results}

\section{Descriptive Statistics}

As outlined in Table 2, means, standard deviations, and Cronbach alphas for the measured variables were calculated. Overall, participants reported moderate to high levels of job characteristics with the means of these dimensions all being above five on the 7-point scale. Autonomy had the highest average $(M=5.56, S D=1.18)$, whereas feedback had the lowest average $(M=4.89, S D=1.27)$. These results indicate that these respondents experienced their job as having different skills, being of high impact, and being part of a bigger job or project. Their job also allowed them the freedom to choose the pace to complete tasks and gave feedback on the employees' performance

LMX scores among employees were also relatively high $(M=5.47, S D=1.19)$, meaning that the employees in this sample had relatively high-quality relationships with their managers. These employees would most likely, for example, defend this manager if he or she was not there to do so, and the employees believe their manager has their best interest at heart. Thus, these employees favor their managers and seem to have beneficial relationships with them.

Organizational commitment scores were not as high as the other two variables, but were still above average. Specifically, the commitment scales (affective $(M=4.72, S D=$ $1.28)$, normative $(M=4.29 S D=1.36)$, continuance $(M=3.97, S D=1.34))$ suggest that these respondents were around average in their level of commitment and willingness to stay at their organization. It should be noted that affective commitment had a higher average than normative and continuance, and normative commitment was higher than 
continuance, meaning that more of these respondents experience affective commitment, an attitudinal attachment to their organization based on shared values and morals. Lastly, some respondents may only remain at their organization because they do not have a better option.

Table 2

Means, Standard Deviations, and Cronbach Alphas of Core Job Dimensions, LMX, and Commitment Dimensions

\begin{tabular}{lrrr}
\hline Variable & Mean & SD & $\alpha$ \\
\hline Job Characteristics & 5.29 & .83 & .71 \\
$\quad$ Skill variety & 5.21 & 1.27 & .70 \\
Feedback & 4.89 & 1.27 & .69 \\
Task significance & 5.45 & 1.11 & .58 \\
Autonomy & 5.56 & 1.18 & .73 \\
Task identity & 5.31 & 1.25 & .68 \\
& & & \\
LMX & 5.47 & 1.19 & .88 \\
& & & \\
Commitment & 4.33 & 1.00 & \\
Affective Commitment & 4.73 & 1.28 & .63 \\
$\quad$ Normative Commitment & 4.30 & 1.36 & .67 \\
Continuance Commitment & 3.97 & 1.34 & .56 \\
\hline
\end{tabular}

\section{Pearson Correlations}

As seen in Table 3, all the job characteristics were positively related to affective commitment, such that the more employees experienced highly impactful jobs in which they managed the job from beginning to end, the tasks themselves vary, the job produced feedback on their performance, and allowed employees choose how to complete the job. If the job scored high on these core job dimensions the employee would feel an 
Table 3

Pearson Correlations for Core Job Dimensions, LMX, and Commitment Dimensions

\begin{tabular}{|c|c|c|c|c|c|c|c|c|c|c|}
\hline & Variable & 1 & 2 & 3 & 4 & 5 & 6 & 7 & 8 & 9 \\
\hline 1 & Skill Variety & -- & & & & & & & & \\
\hline 2 & Task Significance & $.52 * * *$ & -- & & & & & & & \\
\hline 3 & Task Identity & .10 & $.16 *$ & -- & & & & & & \\
\hline 4 & Autonomy & $.37 * * *$ & $.32 * * *$ & $.41 * * *$ & -- & & & & & \\
\hline 5 & Feedback & $.31 * * *$ & $.58 * * *$ & $.40 * * *$ & $.36 * * *$ & -- & & & & \\
\hline 6 & LMX & $.22 * *$ & $.31 * * *$ & $.32 * * *$ & $.46 * * *$ & $.59 * * *$ & -- & & & \\
\hline 7 & $\begin{array}{l}\text { Affective } \\
\text { Commitment }\end{array}$ & $.50 * * *$ & $.58 * * *$ & $.35 * * *$ & $.48 * * *$ & $.51 * * *$ & $.48 * * *$ & -- & & \\
\hline 8 & $\begin{array}{l}\text { Continuance } \\
\text { Commitment }\end{array}$ & .05 & .11 & .11 & .12 & $.17 *$ & .06 & .21 & -- & \\
\hline 9 & $\begin{array}{l}\text { Normative } \\
\text { Commitment }\end{array}$ & $.30 * * *$ & $.28 * * *$ & $.26 * * *$ & $.32 * * *$ & $.37 * * *$ & $.45 * * *$ & $.55 * * *$ & $.31 * * *$ & -- \\
\hline
\end{tabular}


an attachment to the organization and remain as an employee. It should be noted that task significance $(r=.58, p<.001)$ was the most related to affective commitment, whereas, task identity $(r=.35, p<.001)$ was the least related to affective commitment. This leads to the interpretation that having a job with impact was a stronger predictor of the attachment to the organization compared to the task being part of a bigger project or picture.

For the second type of commitment, all job characteristics were significantly related to normative commitment. The strongest relationship was between feedback and normative commitment $(\mathrm{r}=.37, \mathrm{p}<.001)$. Overall, the significant correlations of the job characteristics with normative commitment were not as strong as the relationships with affective commitment. These results indicate that employees who experience jobs that had high impact, skill variety, feedback, and autonomy, and if employees are able to perceive an outcome from their work, the more an employee would have a sense of obligation to give back to the organization. This leads the employee to remain at the organization because of obligation, loyalty and duty.

For the last type of commitment, only feedback $(r=.17, p<.05)$ was significantly related to continuance commitment. Skill variety $(r=.05, p>.05)$, task significance $(r=$ $.11, p>.05)$, task identity $(r=.11, p>.05)$, and autonomy $(r=.12, p>.05)$ were not related to continuance commitment. It should be noted that these correlations were even weaker than the relationships between job characteristics and normative and affective commitment, which suggests these employees only need the job to provide information 
on how they were performing for the current organization to be perceived as better than another external organization.

The moderating variable, LMX, was related to two of the dimensions of commitment. Specifically, LMX was significantly related to affective commitment $(r=.48 p<.001)$, and to normative commitment $(r=.45, p<.001)$, but not continuance commitment $(r=$ $.06, p>.05)$. Thus, a high-quality relationship with one's manager, consisting of mutual trust, respect, and awareness, may lead employees to develop an attitudinal attachment to the organization and remain there because they feel a sense of obligation or attachment to the organization based on values and beliefs. However, high-quality relationships with one's manager does not help convince employees to remain at the organization because there are no other better alternatives. Although LMX was related to each dimension, it should be noted that LMX had a stronger correlation with affective and normative commitment than continuance commitment. Therefore, having a good relationship with one's manager was more related to producing an attachment to the organization because of morals, or producing a sense of loyalty because of obligation and duty.

Pearson correlations were reviewed to determine the relationship of every core job dimension and organizational commitment, as well as the single dimension of LMX. As outlined in Table 3, all the job characteristics were related to one another. These internal correlations between the job characteristics may cause complications in their individual and unique contributions in future analyses because their correlations show overlap between the dimensions. The highest correlations were between skill variety and task significance $(r=.52, p<.001)$, and the correlations between task identity with feedback 
$(r=.40, p<.001)$ and with autonomy $(r=.41, p<.001)$. These correlations may exist because employees need a job to require different skills to be impactful, and information on how they were doing with the choice to complete the tasks on their own terms may help identify their tasks as part of a bigger picture.

In regards to commitment, all three dimensions were related to one another. This overlap between the dimensions could cause an employee to feel multiple types of commitment at once. Therefore, an employee's overall commitment may be due to a combination of attachments, loyalty, and the presence of alternative situations.

Furthermore, this overlap could be due to common or shared antecedents. The highest correlation was between affective and normative commitment $(r=.55, p<.001)$. This stronger relationship may exist because affective and normative commitment are attitudinal beliefs in the organization, whereas continuance commitment is a behavioral reaction to a calculated comparison of external factors.

\section{Test of Hypothesis}

Three hierarchical multiple regression analyses (MRC) were conducted with three steps to observe the interactions at a dimensional level. All five job characteristics were entered in the first step of the analysis. The single dimension of Leader-Member Exchange (LMX) was entered into the hierarchical MRC as the second step. This step was to explore the simple relationship of LMX as an incremental factor before the analysis explores the more complex relationship of moderation. The last step of the MRC was to explore the moderating effect of LMX on the relationship between job 
characteristics and components of commitment. The dimensions of the Job Characteristics Model were multiplied by LMX to create a new variable; this new variable was entered in the last step.

As outlined in Table 4 the results from the first step, in which the five dimensions of the Job Characteristics Model were entered as a set, for affective commitment resulted in $R^{2}=.52, R^{2}$ adj $=.51, F(5,215)=47.38, p<.001$, and accounted for $52 \%$ of the variance in affective commitment. This means, if a job requires various skills, was part of a bigger project, impacts others' lives/work, provides information on the employee's performance, and allows the employee to choose when and where to complete these aspects, the employee will develop an attachment to the organization and continue his or her employment. Every job characteristic added a significant unique contribution to this relationship, specifically, task significance and feedback added the most value to affective commitment $(\beta=.33, t=5.87, \mathrm{p}<.001$ and $\beta=.23, t=4.21, p<.001$, respectively) whereas autonomy, skill variety, and task identity added slightly lower value $(\beta=.18, t=3.12$, and $\beta=.17, t=3.01, p<.01$, and $\beta=.12, t=2.15, p<.05$, respectively). Meaning, a job that can be identified as part of a bigger job or project and one that can provide information on how the employee was performing will be stronger indicators of producing an attitudinal attachment to the organization, compared to impact, autonomy, and variety in skill.

The second step, in which LMX was entered to observe its incremental effect, resulted in $\Delta R^{2}=.01, \Delta F(1,214)=5.22, p<.05$. Therefore, the relationship with one's manager adds a unique contribution to affective commitment above and beyond the 
Table 4

Hierarchical Multiple Regression Analysis: Moderation of Leader-Member ExchangeJob Characteristics Relationship by Affective Commitment

\begin{tabular}{lccc}
\hline Predictor & $\beta$ & $\mathrm{R}^{2}$ & $\Delta \mathrm{R}^{2}$ \\
\hline & & $.52^{* * *}$ & $.52^{* * *}$ \\
Step 1: Independent Variables & $.17^{* *}$ & & \\
Skill variety & $.23^{* * *}$ & & \\
Feedback & $.33^{* * *}$ & & \\
Task significance & $.18^{* *}$ & & \\
Autonomy & $.12^{*}$ & & $.01^{*}$ \\
Task identity & & & \\
& & $.54 * * *$ & .01 \\
Step 2: Incremental Effect & & & \\
LMX & & $.54 * * *$ & \\
Step 3: Interaction & -.19 & & \\
LMX x Skill variety & .26 & & \\
LMX x Feedback & .45 & & \\
LMX x Task significance & -.07 & & \\
LMX x Autonomy & -.43 & & \\
LMX x Task Identity & &
\end{tabular}

$* \mathrm{p}<.05, * * \mathrm{p}<.01, * * \mathrm{p}<.01$ 
dimensions of the Job Characteristics Model. Meaning, high-quality LMX results in employees' experiencing more of an attachment (affective commitment) to the organization beyond just the commitment they would have experienced based on the interactions with their job.

After the confirmation of the effect of LMX as adding an incremental value to the relationship between job characteristics and organizational commitment, LMX by each job characteristic was entered to test its moderating effect. In this last step, when the moderating effect of the LMX on the relationship between the job characteristics and affective commitment was entered as the third step, the result was $\Delta R^{2}=.01, \Delta F(5,209)$ $=.77, p>.05$. Therefore, LMX did not moderate the relationship between job characteristics and affective commitment.

For normative commitment, the dimensions of the Job Characteristics Model were entered into the first step of the hierarchical MRC as outlined in Table 5. The results were $R^{2}=.21, R_{\text {adj }}^{2}=.19, F(5,215)=11.38, p<.001$ and accounted for $21 \%$ of the variance in normative commitment, resulting in the job dimensions being significantly related to normative commitment. The employee perceives the organization giving them a job that results in impact, responsibility in being part of something bigger, the choice to complete his or her work wherever, information on how he or she was performing and the opportunity to use different skills. Therefore, the employee will experience a sense of obligation to return this gift by remaining at the organization or that it was his or her duty to stay loyal and remain at the organization. Contrasting affective commitment in the 
Table 5

Hierarchical Multiple Regression Analysis: Moderation of Leader-Member ExchangeJob Characteristics Relationship by Normative Commitment

\begin{tabular}{|c|c|c|c|}
\hline Predictor & $\beta$ & $R^{2}$ & $\Delta R^{2}$ \\
\hline Step 1: Independent Variables & & $.21 * * *$ & $.21 * * *$ \\
\hline Skill variety & .13 & & \\
\hline Feedback & $.22 * *$ & & \\
\hline Task significance & .07 & & \\
\hline Autonomy & .14 & & \\
\hline Task identity & .09 & & \\
\hline $\begin{array}{l}\text { Step 2: Incremental Effect } \\
\text { LMX }\end{array}$ & & $.26 * * *$ & $.05 * * *$ \\
\hline Step 3: Moderation Interaction & & $.29 * * *$ & .02 \\
\hline LMX x Skill variety & .06 & & \\
\hline LMX x Feedback & .74 & & \\
\hline LMX x Task significance & -.00 & & \\
\hline LMX x Autonomy & -.81 & & \\
\hline LMX x Task Identity & -.40 & & \\
\hline
\end{tabular}


second step, however, normative commitment's relationship with the five dimensions of the Job Characteristics Model resulted in only feedback adding unique contributions to the relationship $(\beta=.22, t=3.15, p<.01)$. These results show that a job must only possess high levels of feedback to have an employee feel obligated to the organization and remain. Therefore, Hypothesis 1 was only partially supported

The results from the second step, in which LMX was added to the hierarchical MRC to observe its incremental value to job characteristics and normative commitment, revealed $\Delta R^{2}=.05, \Delta F(1,214)=15.43, p<.001$. Therefore, the relationship with one's manager added a unique contribution to normative commitment above and beyond the core job dimensions. A high-quality relationship with one's manager affected the overall employee experience leading to the employee to remained loyal to the organization and to be obligated to continue his or her employment above and beyond just the commitment he or she would have experienced based on the job characteristics.

The result in the third step, where LMX as a moderating effect was added in the hierarchical MRC, was $\Delta R^{2}=.02, \Delta F(5,209)=1.38, p>.05$. Therefore, LMX does not moderate the relationship between job characteristics and normative commitment. From these results, one can infer that the relationship with one's manager does not moderate the manner in which an employee experiences the aspects of a job. Therefore, the relationship with the manager did not impact the association between core job dimensions and normative commitment. Hypothesis 2 was not supported.

The last table, Table 6, displays the last component of organizational commitment that was investigated in the MRC. The job characteristics for continuance commitment 
did not result in a significant relationship, $R^{2}=.04, R^{2}$ adj $=.02, F(5,215)=1.65, p>.05$. This result means that job characteristics are not related to continuance commitment. Furthermore, none of the dimensions added any unique contributions. Thus, employees do not need to experience any of the job characteristics to make the calculative comparison between what they have at their current organization and external offers to join another organization. The second and third steps of the hierarchical MRC were also not significant. The second step with the addition of LMX resulted in $\Delta R^{2}=.01, \Delta F$ $(1,214)=1.48, p>.05 ;$ and the last step with the addition of moderating effect resulted in $\Delta R^{2}=.04, \Delta F(5,209)=1.92, p>.05$. Due to the non-significant findings of the moderating effect on all three dimensions of commitment, Hypothesis 3 was not supported. 
Table 6

Hierarchical Multiple Regression Analysis: Moderation of Leader-Member ExchangeJob Characteristics Relationship by Continuance Commitment

\begin{tabular}{|c|c|c|c|}
\hline Predictor & $\beta$ & $R^{2}$ & $\Delta R^{2}$ \\
\hline Step 1: Independent Variables & & .04 & .04 \\
\hline Skill variety & -.05 & & \\
\hline Feedback & .13 & & \\
\hline Task significance & .07 & & \\
\hline Autonomy & .06 & & \\
\hline Task identity & .03 & & \\
\hline $\begin{array}{l}\text { Step 2: Incremental Effect } \\
\text { LMX }\end{array}$ & & .04 & .01 \\
\hline Step 3: Interaction & & .09 & .04 \\
\hline LMX x Skill variety & -.99 & & \\
\hline LMX x Feedback & -.02 & & \\
\hline LMX x Task significance & -.37 & & \\
\hline LMX x Autonomy & .24 & & \\
\hline LMX x Task Identity & .31 & & \\
\hline
\end{tabular}




\section{Discussion}

\section{Summary of Results}

The purpose of this study was to determine if the relationship with a manager can impact the commitment an employee has based on the manner in which a job is designed. In addition, this study aimed to explore the impact of the interaction of LMX with every job characteristic on every component of commitment to observe if the relationship with the manager had more influence on certain job characteristics or certain types of commitment. I tested the hypothesis that the job characteristics would be related to the components of organizational commitment, such that all of the job characteristics would add unique contributions to each type of commitment, individually. Furthermore, I hypothesized that all the job characteristics would be uniquely related to all the dimensions of organizational commitment, that LMX would moderate this relationship and my third hypothesis was to explore the moderating effect of LMX on the core job dimensions and each dimension of organizational commitment.

The results partially supported previous research that there was a significant relationship between the core job dimensions and the three components of organizational commitment. It was revealed that all of the job characteristics added unique contributions to affective commitment, but only feedback added a unique contribution to normative commitment, and none of the job characteristics add value to explaining continuance commitment. These results are in line with studies conducted by Pentareddy and Suganthi (2015) who found a connection between the job characteristics and affective commitment, but not with continuance commitment. However, these results also 
found a relationship between the job characteristics and normative commitment, which Pentareddy and Suganthi did not find.

These results may have occurred because the psychological states (meaningfulness, responsibility, and knowledge) resulting from the job characteristics may relate more to affective commitment than the other two components because affective commitment is an attitudinal attachment to the organization based on similar morals and values (Hackman \& Oldham, 1975). All of the job characteristics may also provide unique contributions to affective commitment because every job characteristic engages with the three psychological states. These three psychological states may be related to one's morals and values because when the organization provides the employee with space and resources to engage with his or her own morals and values, the employee may view the organization as having similar morals and values. This perception of shared morals and values produces an attitudinal attachment. For example, an employee may value meaning and responsibility in his or her life, and when a job fulfills these values the employee may view the entire organization as fulfilling these values. and therefore, the employee experiences an attachment to the organization.

Unlike affective commitment, only the job characteristic of feedback added a unique contribution to normative commitment. This result may due to the fact that feedback continuously provides information on the employee's performance, which can be interpreted as a gracious act and one that needs to be repaid. Therefore, this extra information causes the employee to feel that he or she owes the company more of his or her time. For example, if an employee is receiving feedback from the job, he or she may 
feel an internal sense of loyalty and obligation because the employee does not want to disappoint or harm the company through his or her absence.

Lastly, a relationship between the core job dimensions and continuance commitment may not exist because the core job dimensions result in the three psychological states, which are an internal experience, and employees experience continuance commitment because of external factors, such as competing job offers, mortgages, salary, etc. Therefore, the internal experience of meaningfulness, knowledge and responsibility, which occur because of the core job dimensions, is not related to the calculation of external factors associated with continuance commitment. This internal element of the Job Characteristics Model may be the reason that there was not a significant relationship between the core job dimensions and continuance commitment.

The relationships between LMX and each dimension of organizational commitment may be explained by the attitudinal nature of affective and normative commitment compared to the behavioral nature of continuance commitment. LMX is based on the employee's perception of the relationship with his or her manager. This perception comes from mutual trust, awareness of one another, and respect. If the manager exhibits trust, awareness and respect, the employee will view the manager favorably and approve of them. These elements of shared perceptions, similar beliefs on trust, awareness, and respect, and an approval of one another mirrors the attitudinal attachment of affective commitment. LMX adds a unique contribution to normative commitment because the manager is providing additional support, encouragement and resources, which the employee feels obligated to return through continuing his or her employment at the 
organization. LMX does not add a unique contribution to continuance commitment because, as mentioned before, continuance commitment is dependent on external factors compared to intrinsically motivating aspects of the employee experience. The LMX perceptions are based on an employee's belief, approval, and opinion of his or her manager which are personal preferences and beliefs of the employee. An employee may separate an external situation from his or her personal preference. Therefore, LMX, based on personal preference, would not impact the employee's continuance commitment.

LMX may not impact the perceptions of the core job dimensions on organizational commitment because the employee experiences the manager separately from the job. However, the incremental addition of LMX above and beyond the job characteristics shows that the relationship with a manager is part of the entire picture that the employee experiences and is a critical element in predicting if an employee is committed and what type of commitment he or she experiences. Therefore, it is believed that LMX works together with the dimensions of the job to further convince the employee that the organization as a whole has similar moral and values and therefore produces a strong attachment and affective commitment.

\section{Theoretical Implications}

Overall, this study adds to previous literature, as this was the first study to examine the moderating effects of LMX on the relationship between job characteristics and organizational commitment. The present study also contributes to previous research by examining the dimensions of the Job Characteristics Model and organizational commitment in regards to its unique contribution to commitment and LMX. 
This study adds to the current literature regarding the relationship between job characteristics and organizational commitment. Expanding on the research conducted by Pentareddy and Suganthi (2015), who found that the entire JCM with or without the psychological states was positively related to high affective commitment, this study also found that most of the job characteristics were related to normative commitment; however, none were related to continuance commitment. Furthermore, this study contradicts Hsu and Liu (2016), who found that task identity did not relate to affective commitment, as this study found that every core job dimension added a unique contribution to affective commitment. Lastly, this study added to the literature by investigating the relationship between job characteristics and continuance commitment, something no previous research had investigated.

This study also adds to the literature regarding the impact and influence of the manager on the relationship of job design and organizational commitment. Previous research from Pentareddy and Suganthi (2015) found that leader complexity enhanced the relationship between core job dimensions and organizational commitment. However, this study did not find a significant moderating effect of LMX on the relationship between core job dimensions and organizational commitment.

\section{Practical Implications}

Organizations can use the results of this study to help focus its efforts on increasing employee commitment, and more specifically, increasing a particular type of commitment. Previous researchers have stated that the strongest type of commitment may be affective commitment (Luchak \& Gellatly, 2007) because there is an attitudinal 
attachment based on morals, values and beliefs. To have affectively committed employees, organizations should design jobs to have high levels of the core job dimension and encourage managers to develop mutual trust, respect, and awareness with their reports. To have employees normatively committed, organizations should ensure jobs have high levels of feedback on the employee's performance and have managers develop high-quality relationships with their reports.

These implications are important to the practices of organizations because there is a current trend to continually increase salaries and 'throw money at the problem' to solve the retention problem (Lipman, 2014). However, the results from this study indicate that providing the extrinsic factor of money may only affect those who are continuance committed employees - those who are only at the organization because there is no other better option. However, if an organization wants employees who have a deep attachment and connection to the organization, the organization should analyze how jobs are designed and the relationships between managers and employees.

\section{Strengths and Weaknesses}

One of the strengths of this study was that it was conducted with a sample of crossfunctional and global employees across various industries, companies, and levels of career. A majority of previous studies have focused on one department, job family, or comparing cultures, which limits the generalizability of the findings. Observing the relationships across countries, companies, and careers allows for a better understanding of manager-employee relationships, job design, and organizational commitment. 
Another strength of this study was the examination and comparison of different job characteristics and dimensions of organizational commitment. Though various studies examined specific relationships between job characteristics and overall organizational commitment, there has not been a study conducted observing the moderating effect of LMX on the relationship of core job dimension to the component of commitment,

A major limitation of the present study is that the variables of interest were highly correlated with one another. This was a limitation because high correlations among the variables likely limit the unique contributions of the job characteristics on the components of organizational commitment.

Another limitation of the study was the scales used to measure the variables. The scales were adopted from the original surveys from previous researchers. Adaptations can limit limits the reliability and validity of these scales. Future researchers should explore reliable scales for measuring leader-member exchange, job characteristics, and organizational commitment.

\section{Future Research}

Future research should consider the moderating effect of one's own morals and values on the relationship between job characteristics and organizational commitment. As mentioned before, LMX and the core job dimensions may overlap with an employee's personal morals and values; which are crucial elements in creating the attachment in affective commitment. Future researchers should also observe if LMX mediates the relationship between core job dimension and organizational commitment as other research has looked at LMX as a mediator. Furthermore, employees apply and get a job 
before they meet their manager. Therefore, the job can be viewed as coming first and the impact of a manager could mediate the relationship of that job and the outcome of organizational commitment.

\section{Conclusion}

Given the various benefits of organizational commitment, predicting and increasing organizational commitment is a topic of great interest. As seen in the present study, job characteristics were indicative of affective and normative commitment. Although the relationship with one's manager did not influence the core job dimensions, it does add incremental value to the employee's overall experience and adds to the explanation of what elements of an employee's experience leads to his or her organizational commitment. This study corroborates previous research and expands current literature by examining this relationship across countries, industries, and careers. However additional research is needed to factor in personal morals and values, and whether LMX can be a mediator in the relationship. 


\section{References}

Abbott, J. b., Boyd, N. G., \& Miles, G. (2006). Does type of team matter? An investigation of the relationships between job characteristics and outcomes within a team-based environment. Journal of Social Psychology, 146, 485-507.

Bang, H. (2011). Leader-member exchange in nonprofit sport organizations the impact on job satisfaction and intention to stay from the perspectives of volunteer leaders and followers. Nonprofit Management \& Leadership, 22, 85-107.

Becker, H. S. (1960). Notes on the concept of commitment. American Journal of Sociology, 66, $32-40$.

Blau, P. M. (1964). Exchange and power in social life. Piscataway, NJ: Transaction Publishers.

Buch, R. (2015). Leader-member exchange as a moderator of the relationship between employeeorganization exchange and affective commitment. The International Journal of Human Resources Management, 26, 59-79.

Buchanan, B. (1974). Building organizational commitment: The socialization of managers in work organizations. Administrative Science Quarterly, 19, 533-546.

Chang, S. C., \& Lee, M. S. (2006). Relationships among personality traits, job characteristics, job satisfaction and organizational commitment - An empirical study in Taiwan. The Business Review, 6, 201-207.

Cogliser, C. C., Schriesheim, C. A., Scandura, T. A., \& Gardner, W. L. (2009). Balance in leader and follower perceptions of leader-member exchange: Relationships with performance and work attitudes. The Leadership Quarterly, 20, 452-465.

D'Amato, A., \& Herzfeldt, R. (2008). Learning orientation, organizational commitment and talent retention across generations a study of European managers. Journal of Managerial Psychology, 23, 929-953.

Eisenberger, R., Huntington, R., Hutchison, S., \& Sowa, D. (1986). Perceived Organizational Support. Journal of Applied Psychology, 71, 500-507.

Eisenberger, R., Stinglhamber, F., Becker, T. E., Karagonlar, G., Neves, P., Gonazalez-Morales, G. M., \& Steiger-Mueller, M. (2010). Leader-member exchange and affective organizational commitment: The contribution of supervisor's organizational embodiment. Journal of Applied Psychology, 95, 1085-1103.

Emery, F. E., \& Trist, E. L. (1960). Socio-technical systems. In: Churchman, C.W. Verhulst, M. Management Science Models and Techniques. Oxford, UK: Pergamon Press, pp. 83-97.

Field, L. K., \& Buitendach, J. H. (2014). Work engagement, organizational commitment, job resources and job demands of teachers working within disadvantaged high schools in Kwazulu-Natal, South Africa. Journal of Psychology in Africa, 22, 97-95. 
Fishbein, M., \& Ajzen, I. (1975). Belief, attitude, intention, and behavior: An introduction to theory and research. Reading, MA: Addison-Wesley.

Graves, L. M., \& Luciano, M. M. (2013). Self-determination at work: Understanding the role of leader-member exchange. Department of Management, 37, 518-536.

Gunlu, E., Aksarayli, M., \& Percin, N. S. (2010). Job satisfaction and organizational commitment of hotel managers in Turkey. International Journal of Contemporary Hospitality Management, 22, 693-717.

Hackman, J. R., \& Oldham, G. R. (1975). Development of the job diagnostic survey. Journal of Applied Psychology, 60, 159-170.

Hackman, J. R., \& Oldham, G. R. (1980). Work Redesign. Boston, MA: Addison-Wesley.

Hackman, R. J., \& Oldham, G. R. (1976). Motivation through the design of work: Test of a theory. Organizational Behavior and Human Performance, 16, 250-279.

Herzberg, F., Mausner, B., \& Snyderman, B. B. (2011). The motivation to work. Piscataway: Transaction Publishers.

Hrebiniak, L. G., \& Alutto, J. A. (1972). Personal and role-related factors in the development of organizational commitment. Administrative Science Quarterly, 17, 555-573.

Hsu, L. C., \& Liao, P. W. (2016). From job characteristics to job satisfaction of foreign workers in Taiwan's construction industry: The mediating role of organizational commitment. Human Factors and Ergonomics in Manufacturing \& Service Industries, 26, 243-255.

Humphrey, S. E., Nahrgang, J. D., \& Moregson, F. P. (2007). Integrating motivational, social, and contextual work design features: A meta-analytic summary and theoretical extension of the work design literature. Journal of Applied Psychology, 9, 1332-1356.

Jackson, T. A., Meyer, J. P., \& Wang, X.-H. (2013). Leadership, commitment, and culture: A meta-analysis. Journal of Leadership \& Organizational Studies, 20, 84-106.

Jaiswal, D., \& Dhar, R. L. (2015). Impact of perceived organizational support, psychological empowerment and leader member exchange on commitment and its subsequent impact on service quality. International Journal of Productivity and Performance Management, $65,58-79$.

Joao, T. F., \& Coetzee, M. (2012). Job retention factors, perceived career mobility and organizational commitment in the South African financial sector. Australian Academic Press, 22, 69-76.

Joo, B.-K. (2010). Organizational commitment for knowledge workers: The roles of perceived organizational learning culture, leader-member exchange quality, and turnover intention. Human Resource Development Quarterly, 21, 68-85. 
Kanter, R. M. (1968). Commitment and social organization: A study of commitment mechanisms in utopian communities. American Sociological Review, 33, 499-517.

Koslowsky, M. (1990). Staff line distinction in job and organizational commitment. Journal of Occupational Psychology, 63, 167-173.

Liden, R. C., Sparrowe, R. T., \& Wayne, S. J. (1997). Leader-member exchange theory: The past and potential for the future. Research in Personnel and Human Resources Management, $15,47-120$.

Lipman, V. (2014, August 4). People leave managers, not companies. [Blog Post]. Retrieved from https://www.forbes.com/sites/victorlipman/2015/08/04/people-leave-managers-notcompanies/\#5c05111647a9

Liu, Z., Cai, Z., Li, J., Shi, S., \& Fang, Y. (2013). Leadership style and employee turnover intentions: A social identity perspective. Career Development International, 18, 305-324.

Luchak, A. A., \& Gellatly, I. R. (2007). A comparison of linear and nonlinear relations between organizational commitment and work outcomes. Journal of Applied Psychology, 92, 786793.

Madi, M., Abu-Jarad, I., \& Algahtani, A. M. (2012). Employees' perception and organizational commitment: A study on the banking sector in Gaza, Palestine. International Journal of Business and Social Science, 3, 299-32.

Marsh, R. M., \& Mannari, H. (1977). Organizational commitment and turnover: A prediction study. Administrative Science Quarterly, 22, 57-75.

Meyer, J. P., \& Allen, N. J. (1988). Links between work experiences and organizational commitment during the first year of employment: A longitudinal analysis. Journal of Occupational Psychology, 61, 195-209.

Meyer, J. p., \& Allen, N. J. (1991). A three-component conceptualization of organizational commitment. Human Resource Management Review, 1, 61-89.

Meyer, J. P., \& Allen, N. J. (1997). Commitment in the workplace. Thousand Oaks, CA: Sage Publications.

Meyer, J. P., \& Allen, N. J. (2004). TCM Employee Commitment Survey Academic Users Guide 2004. London, UK: The University of Western Ontario.

Meyer, J. P., Allen, N. J., \& Smith, C. A. (1993). Commitment to organizations and occupations: Extension and test of a three-component conceptualization. Journal of Applied Psychology, 78, 539-551.

Morrow, P. C. (1983). Concept redundancy in organizational research: The case of work commitment. Academy of Management Review, 8, 486-500. 
Mowday, R. T., Koberg, C. S., \& McArthur, A. W. (1984). The psychology of the withdrawal process: A cross-validation test of Mobley's intermediate linkages model of turnover in two samples. Academy of Management Journal, 27, 79-94.

Mowday, R. T., Porter, L. W., \& Steers, R. M. (1982). Employee-organization linkages The Psychology of Commitment, Absenteeism, and Turnover. London, UK: Academic Press Inc.

Mowday, R. T., Steers, R. M., \& Porter, L. W. (1979). The measurement of organizational commitment. Journal of Vocational Behavior, 14, 224-247.

O'Reilly, C. A., Parlette, G. N., \& Bloom, J. R. (1980). Perceptual measures of task characteristics: The biasing effects of differing frames of reference and job attitudes. Academy of Management Journal, 23, 118-131.

Ozturk, A. B., Hancer, M., \& Young, I. J. (2014). Job characteristics, job satisfaction, and organizational commitment for hotel workers in Turkey. Journal of Hospitality,

Marketing \& Management, 23, 294-313.

Parker, S. K., Wall, T. D., \& Cordery, J. L. (2001). Future work design research and practice: Towards an elaborated model of work design. Journal of Occupational and Organizational Psychology, 74, 413-440.

Pentareddy, S., \& Suganthi, L. (2015). Building affective commitment through job characteristics, leadership, and empowerment. Journal of Management \& Organization, 21, 307-320.

Piccolo, R. F., Greenbaum, R., Dan Hartog, D. N., \& Folger, R. (2010). The relationship between ethical leadership and core job characteristics. Journal of Organizational Behavior, 31, 259-278.

Porter, L. W., Crampon, W. J., \& Smith, F. J. (1976). Organizational commitment and managerial turnover: A longitudinal study. Organizational Behavior and Human Performance, 15 , 87-98.

Porter, L. W., Steers, R. M., \& Mowday, R. T. (1974). Organizational commitment, job satisfaction, and turnover among psychiatric technicians. Journal of Applied Psychology, 59, 603-609.

Portoghese, I., Galletta, M., Coppola, R. C., Finco, G., \& Campagna, M. (2014). Burnout and workload among health care workers: The moderating role of job control. Safety and Health at Work, 5, 152-157.

Reichers, A. E. (1985). A review and reconceptualization of organizational commitment. Academy of Management Review, 10, 456-476. 
Ryan, R. M., \& Deci, E. L. (2000). Intrinsic and extrinsic motivations: Classic definitions and new directions. Contemporary Educational Psychology, 25, 54-67.

Salancik, G. (1977). Commitment and control of organizational behavior and belief. In G. E. In B. Stees and Salancik, New Directions in Organizational Behavior (pp. 1-54). Chicago, IL: St. Clair Press.

Srivastava, A. P., \& Dhar, R. L. (2016). Impact of leader member exchange, human resource management practices and psychological empowerment on extra role performances, the mediating role of organizational commitment. International Journal of Productivity and Performance Management, 65, 351-377.

Stebbins, R. A. (1970). Career: The subjective approach. The Sociological Quarterly, 11, 32-49.

Steers, R. M., \& Spencer, D. G. (1977). The role of achievement motivation in job design.

Journal of Applied Psychology, 62, 472-479.

Wallace, J. (1995). Corporatist control and organizational commitment among professionals: The case of lawyers working in law firms. Social Forces, 73, 811-839.

Wang, X., Ma, L., \& Zhang, M. (2014). Transformational leadership and agency workers' organizational commitment: The mediating effect of organizational justice and job characteristics. Social Behavior and Personality: An International Journal, 42, 25-36. 


\section{APPENDIX}

Survey items

Leader-Member Exchange Items

1. Have you ever been employed with a manager?

2. My manager understands my job problems and needs

3. My manager recognizes my potential.

4. I know how satisfied my manager is with what I do.

5. My manager would use his or her power to help me solve problems in my work.

6. I would defend and justify my manager's decisions even if they were not present do so themselves.

\section{Organizational Commitment Items}

\section{Affective Commitment}

7. I really feel as if this organization's problems are my own.

8. This organization has a great deal of personal meaning for me.

9. I do not feel a strong sense of "belonging" to my organization.

\section{Normative Commitment}

10. I owe a great deal to my organization

11. I would feel guilty if I left my organization now.

12. I do not feel any obligation to remain with my current employer.

\section{Continuance Commitment}

13. Right now, staying with my organization is a matter of necessity as much as desire.

14. I feel that I have too few options to consider leaving this organization.

15. Too much of my life would be disrupted if I decided I wanted to leave my organization now.

Job Characteristics Model Items

Skill Variety

16. My job requires me to do many different things at work using a variety of skills and talents.

17. My job requires me to use a number of complex or high-level skills.

18. My job is quite simple and repetitive. 


\section{Task Identity}

19. My job provides me the chance to completely finish the pieces of work I begin.

20. My job involves doing a "whole" and identifiable piece of work that has an obvious beginning and end.

21. My job is arranged so that I do not have the chance to do an entire piece of work from beginning to end.

\section{Task Significance}

22. My job is not very significant or important in the broader scheme of things.

23. In my job, other people are affected by how well my work is done.

24. The results of my work significantly affect the lives or well-being of other people

\section{Autonomy}

25. My job permits me to decide on my own how to go about doing the work.

26. My job gives me chances to use my personal initiative or judgment.

27. My job gives me considerable opportunity for independence and freedom.

\section{Feedback}

28. Just doing the work required by my job provides chances for me to figure out how well I am doing.

29. My job provides me with information about how well I am doing my job (aside from any feedback my co-workers or supervisors may provide).

30. My job provides very few clues about whether or not I am performing my job well.

Demographic Items

31. What is your current employment status?

32. What is your gender?

33. What is your age?

34. How long have you worked at your current organization?

35. How long have you worked with your manager? 